\title{
Visualization Quality Achievement Program by Using Inference System Mamdani Method
}

\author{
Mohamad Irfan ${ }^{1}$, Wildan Budiawan Zulfikar ${ }^{2}$, Ivan Adrian ${ }^{3}$ \\ \{irfan.bahaf@uinsgd.ac.id ${ }^{1}$, wildan.b@uinsgd.ac.id ${ }^{2}$,ivan.adrian@student.uinsgd.ac.id ${ }^{3}$ \} \\ Department of Informatics, Sunan Gunung Djati Bandung State Islamic University, \\ J1. AH Nasution No. 105, Bandung, West Java, Indonesia ${ }^{1,2,3}$ \\ Asia E University Kualalumpur, Malaysia ${ }^{1}$
}

\begin{abstract}
Quality of education is the crucial thing, one of the factors that affect the quality of education is a teacher. In higher education, teachers/lecturers play as an important role in the quality of graduates. To improve the quality of the graduates is required qualified lecturers, both in terms of assessment of students and other aspects of learning. One way to know the quality of teachers/lecturers in teaching and learning process is by doing the performance evaluation of lecturers. In the process of evaluation, it needs an indicator which is used as a benchmark whether it is good or not related to the lecturer performance. The use of Mamdani Inference System Method is very appropriate to find the value that used as an indicator by using two input variables namely lecturer value and survey result value. The first step is to determine the input and output variables that are set of defects. The second is to convert the input variable into fuzzy set with fuzzification process. Furthermore, the data of fuzzy set is processed with maximum method. The final step is to turn the output into a set in the defuzzification process using the Center of Average method, thus, it will get the desired results for the output variable. The result of the calculation using the Inference System Mamdani method found that the value in a variable of lecturer with values 61 and the value of the survey result with values 83 is 81 .
\end{abstract}

Keywords: Quality, Inference System Mamdani, Fuzzy Set, Fuzzification, Rule Evaluation, Defuzzification.

\section{Introduction}

The development of information systems and electronic media has affected the distribution of data and information. Various data and information are displayed in various media, one of which is the internet. The form of presentation of information that is dynamic, interactive, systematic, and easily interpreted is the main thing in processing data into information in cyberspace. One way or technique that can be used in processing data into information is visualization techniques.[1]

Executive Information System (EIS) is one type of management information systems to facilitate and support the information and decision-making required of senior executives by providing easy access to information both from inside and outside that is relevant to the 
organization's objectives. This is usually considered as a form of a decision support system (SPK).

Visualization technique is the conversion of data into a visual format or table so that the characteristics of data and relations between items of data or attributes can be analyzed and reported. Visualization techniques enable people to capture the concept of data displayed as humans are basically easier to interpret an image rather than text that describes the meaning of it. Visualization techniques can be applied to information systems or web-based applications with database connections, so that data can be processed and displayed dynamically, real time and can be accessed by anyone, anywhere, anytime. It aims to expand the use of the data.[2]

The success of lecturer performance is a main program for a university. This is because the role of the lecturer is very important for a college, if the performance of the lecturer is really good it will greatly affect the college itself. In determining whether the lecturer has truly carried out his/her obligations seriously, a lecturer performance evaluation is needed. Performance assessment is conducted to provide motivation for lecturers to improve its performance and improve the quality of higher education.[3]

For each university, a quality is the main agenda and improving quality is the most important task. Quality is regarded as a concept that is confusing and difficult to measure, it would require an indicator of achievement in order to achieve the quality of programs that have been created, that will serve as the program evaluation (as the performance of lecturers).[4] In evaluating the performance of lecturers, it is done manually by superiors or students, namely by evaluating questionnaires, but in this assessment it is feared that there will be an invasion of an assessment. This is a trigger factor for the deteriorating performance of lecturers.

The Mamdani Inference System method is the right method in evaluating lecturer performance, because it is very flexible and tolerant of existing data. The Mamdani Inference System has many advantages, which are more intuitive, that accepted by many parties. Determination analysis based on fuzzy approach is more efficient than the approach using a number of forecasting methods. By doing a fuzzy approach, it produces output that is closer to the actual situation.

\section{Research Methods}

This study uses several methods for collecting the data used in application development, is as follows:

1. Literature Study

Data collection is done by studying theories from various books and journals or the internet that can be used as supporting sources of research.

2. Observation

Collect some customer data and ask questions with a credit analyst about what problems often become obstacles in his work.

3. Prototype Software Development Method[1]

a. Define the overall objective and identify known needs.

b. Design quickly as a basis for making prototypes.

c. Test and evaluate the prototype and then make additions and improvements to the prototype that has been made. 


\section{A. Software Modeling}

DFD is a logical model of data or process that is created to describe where the origin of the data and the destination where the data out of the system, where data is stored, what processes generate data and interaction between the stored data and its process that imposed on the data. DFD describes data storage in a process that transforms data. DFD shows the relationship between data and the process on the system. [1]

\section{B. Mamdani Inference System}

1. Analysis of valuation rules

Assessment of lecturer performance is carried out by giving values to existing criteria. Assessment starts from the numbers 0 to 100 , with 100 being the largest value and the value is taken from the lecturer assessment data on students and survey data conducted in each semester. After that, the average value for each criterion is sought, so that the average value of the lecturer is obtained and the average score of the student survey results. Both of these averages will be used as variables for determining the performance of lecturers using fuzzy logic in processing. The process begins with the formation of membership degrees. Representation of membership degrees for the average variable of lecturer scores and the average score of student survey results can be seen in Figure 2.1. [5]

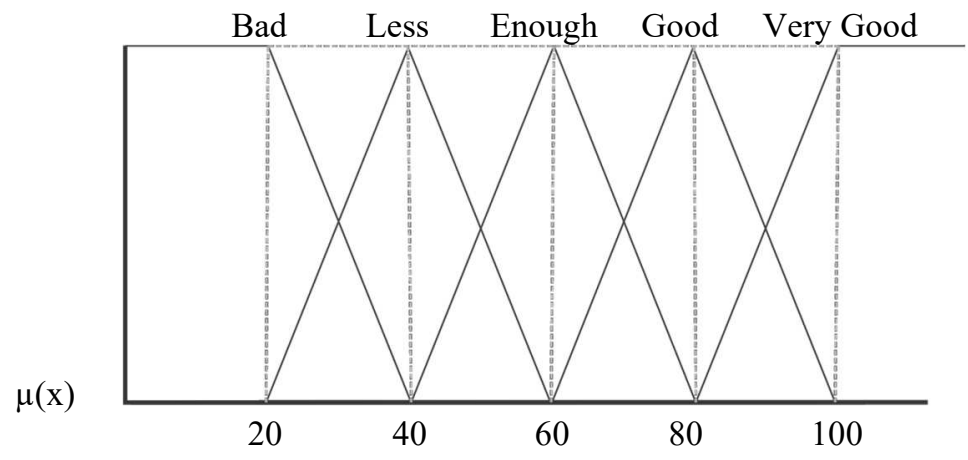

Fig. 1 Membership functions in the fuzzy set

After determining the degree of membership for each fuzzy set, then the non-zero value will be included in the valuation rules used to determine the final result. The assessment rules are obtained by combining the two variables, namely the average value of the lecturer and the average value of the results of the student survey.[5]

The speaker universe for lecturer variables gives $\mathrm{A}$, attendance of lecturers and its survey results: [0 100$]$

Fuzzy set domain:

$\begin{array}{ll}\text { Bad } & =\left[\begin{array}{ll}0 & 40\end{array}\right] \\ \text { Less } & =\left[\begin{array}{ll}20 & 60\end{array}\right] \\ \text { Enough } & =\left[\begin{array}{ll}40 & 80\end{array}\right] \\ \text { Good } & =\left[\begin{array}{ll}60 & 100\end{array}\right] \\ \text { Very Good } & =\left[\begin{array}{ll}80 & 100\end{array}\right]\end{array}$


The membership function of the lecturer variable that gives A, lecturer attendance, and the results of the lecturer survey.

$$
\begin{aligned}
& \text { ○ } \mu \mathrm{Bad}=\left\{\begin{array}{lc}
1 & ; \quad x \leq 20 \\
\frac{40-x}{40-20} ; & 20 \leq x \leq 40 \\
0 ; & x \geq 40
\end{array}\right. \\
& \text { ○ } \quad \mu \text { Less }=\left\{\begin{array}{cc}
0 ; & x \leq 20 \text { atau } x \geq 60 \\
\frac{x-20}{40-20} ; & 20 \leq x \leq 40 \\
\frac{60-x}{60-40} ; & 40 \leq x \leq 60
\end{array}\right. \\
& \text { ○ } \mu \text { Enough }=\left\{\begin{array}{cc}
0 ; & x \leq 40 \text { atau } x \geq 80 \\
\frac{x-40}{60-40} ; & 40 \leq x \leq 60 \\
\frac{80-x}{80-60} ; & 60 \leq x \leq 80
\end{array}\right. \\
& \quad \mu \text { Good }=\left\{\begin{array}{lc}
0 ; & x \leq 60 \text { atau } x \geq 100 \\
\frac{x-20}{40-20} ; & 60 \leq x \leq 80 \\
\frac{60-x}{60-40} ; & 80 \leq x \leq 100
\end{array}\right. \\
& \text { o } \quad \mu \text { Very Good }=\left\{\begin{array}{cl}
0 ; & x \leq 80 \\
\frac{x-100}{100-80} ; & 80<x \leq 100 \\
1 ; & x=100
\end{array}\right.
\end{aligned}
$$

The value to be used in the defuzzification process is obtained in two stages. The first stage, namely by combining the degrees of membership from the average variable lecturer value $(\mu \mathrm{A})$ and the degree of membership of the average variable survey results $(\mu \mathrm{B})$ with the following formula.[5]

$$
\mu \mathrm{A} \cap \mathrm{B}(\mathrm{x})=\min [\mu \mathrm{A}(\mathrm{x}), \mu \mathrm{B}(\mathrm{x})]
$$

The second stage, namely the selection of the degree of membership that will be used in the defuzzification process using the following formula.

$\mu \mathrm{A} v \mathrm{~B}(\mathrm{x})=\max [\mu \mathrm{A}(\mathrm{x}), \mu \mathrm{B}(\mathrm{x})]$

The next process is defuzzification. The input from the defuzzification process is a fuzzy set and the output is a value (crisp). The technique used is center of average defuzzifier. The final results of the assessment will be grouped with the following range of values:

- Total value greater than or equal to 75 stated good.

- The total value of less than 75 expressed less well. 
2. Analysis using the Mamdani Inference System

Table 1 Lecturer Data

\begin{tabular}{lll}
\hline Name & Lecturer Value & Value of Survey Results \\
\hline Mohamad Wildannudin & 61 & 83 \\
\hline
\end{tabular}

The value of membership of the set is feasible, more feasible and most feasible than the variable average value of the lecturer:

$\mu$ Value of Good Lecturer [61]

$\mu$ Value of Enough [61]

$$
\frac{x-60}{20}=\frac{61-60}{20}=0,05
$$

$$
\frac{80-x}{20}=\frac{80-61}{20}=0,95
$$

The value of membership of the set is feasible, more feasible and most feasible than the average variable of the survey results:

$\mu$ Result of Very Good Survey [83]

$\mu$ Results of Good Survey [81]

$$
\frac{x-80}{20}=\frac{83-80}{20}=0,15
$$

$$
\frac{100-x}{20}=\frac{100-83}{20}=0,85
$$

1. Function of Implications

Inference Machine:

[R1] IF Average Score of Lecturer B AND Average Survey Results A THEN Value A = $\operatorname{Min}(0,05 ; 0,15)=0,05$

[R2] IF Average Score of Lecturer B AND Average Survey Result B THEN Value B = $\operatorname{Min}(0,05 ; 0,85)=0,05$

[R3] IF Average Score of Lecturer C AND Average Survey Results A THEN Value B = $\operatorname{Min}(0,95 ; 0,15)=0,15$

[R4] IF Average Value of Lecturer C AND Average Survey Results B THEN Value B = $\operatorname{Min}(0,95 ; 0,85)=0,85$

2. Composition of Rules

Max Function (Aggregation)

A. Aggregation (max function) from Rule 1 is in the following picture: 


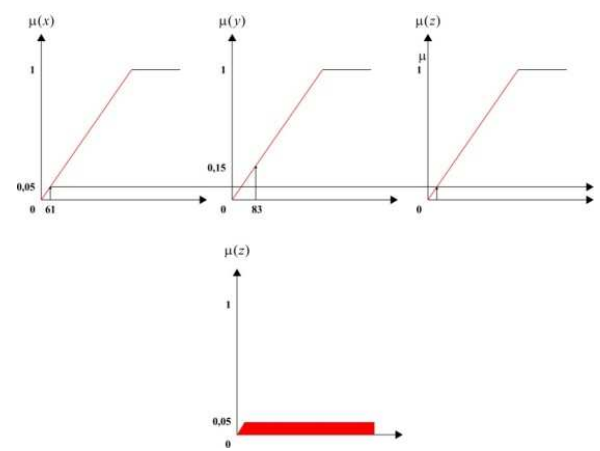

Fig. 2 Aggregation of Rule 1

B. The aggregation (max function) of Rule 2 is in the following picture:
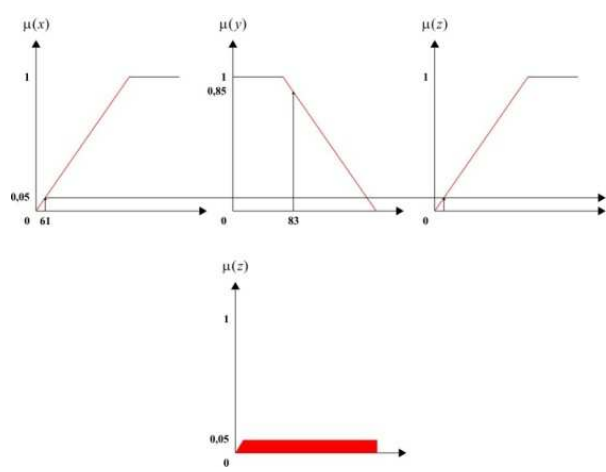

Fig. 3 Aggregation of Rule 2

C. Aggregation (max function) Rule 3 is in the following picture:
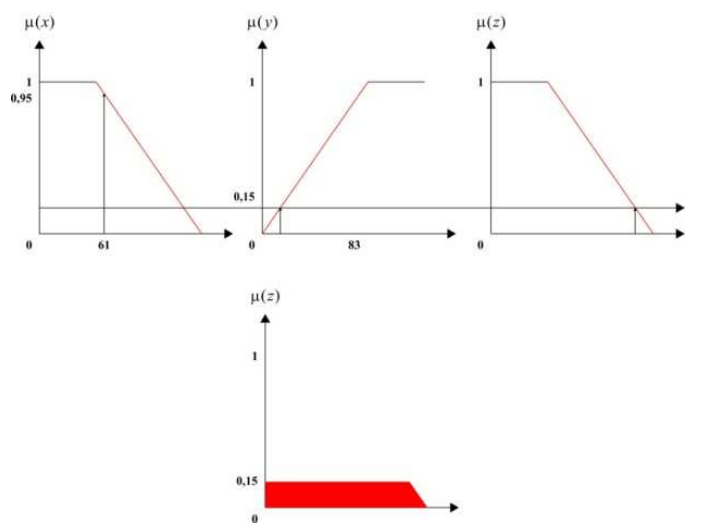

Fig. 4 Aggregation of Rule 3 
D. Aggregation (max function) Rule 4 is in the following picture:
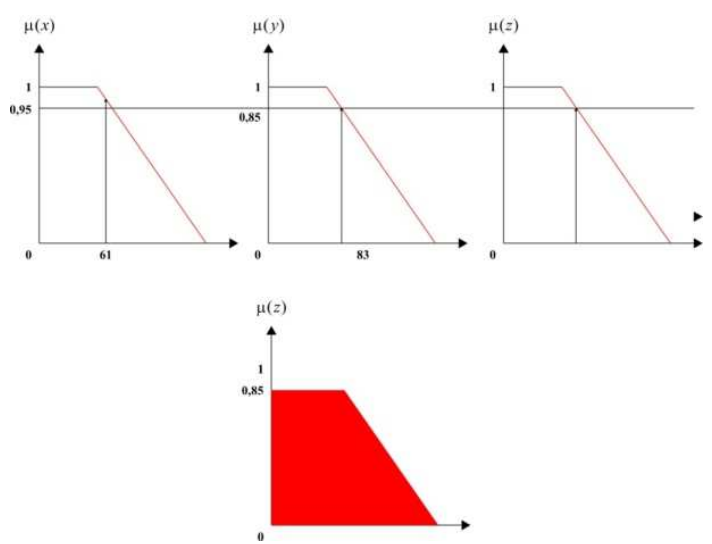

Fig. 5 Aggregation of Rule 4

3. Defuzzification

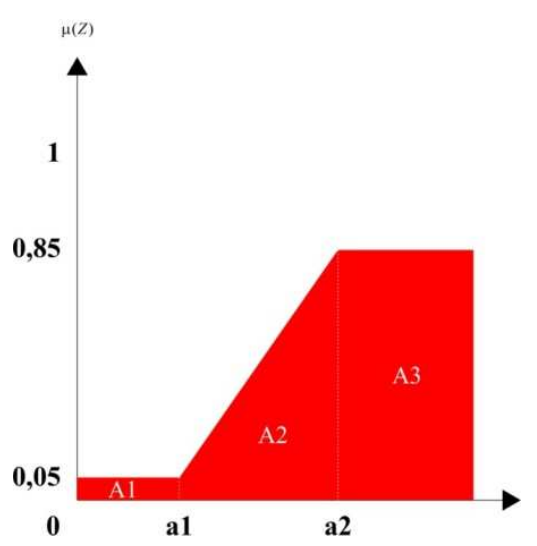

Fig. 6 Defuzzification

$$
\begin{aligned}
& \mathrm{a} 1=0,05 \quad \mathrm{a} 2=0,85 \\
& \mathrm{z} 1=100 \mathrm{z} 2=80 \\
& \frac{0,05 * 100+0,85 * 80}{0,05+0,85}=\frac{72}{0,9}=81,11=81
\end{aligned}
$$

As per the calculation, the lecturer with the name Mohamad Wildannudin gets the final score of 81 and is declared GOOD, as the final value exceeds the minimum limit of 75 . 


\section{Results and Discussion}

\subsection{Context Diagram}

Context Diagram is a flow that describes the relationship between systems with entities.

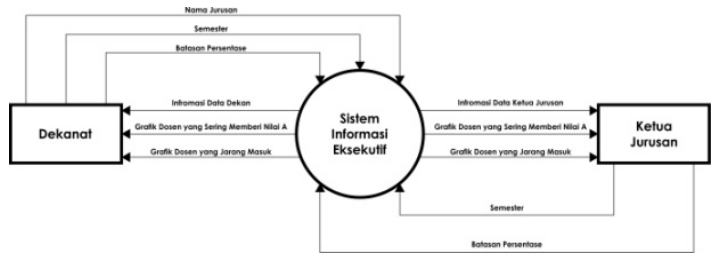

Fig. 7 Context Diagram

\subsection{Data Flow Diagram}

Data Flow Level 1 diagram describes the activities of data flows that comprise this system.

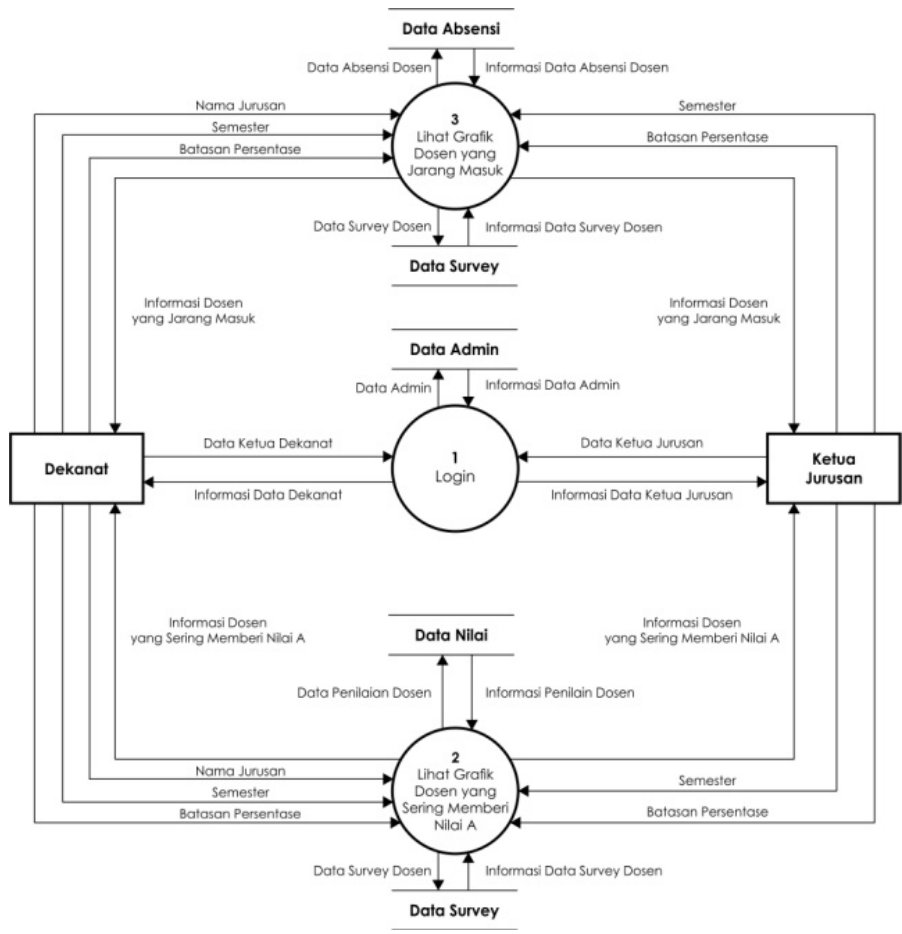

Fig. 8 Data Flow Diagram 


\subsection{Research results}

This page is a security on this system. Login is useful for logging in to the system by entering the username and password that was previously registered. Therefore, when a user logs in, it will automatically enter the system that is running. Display login as shown in Figure 9.

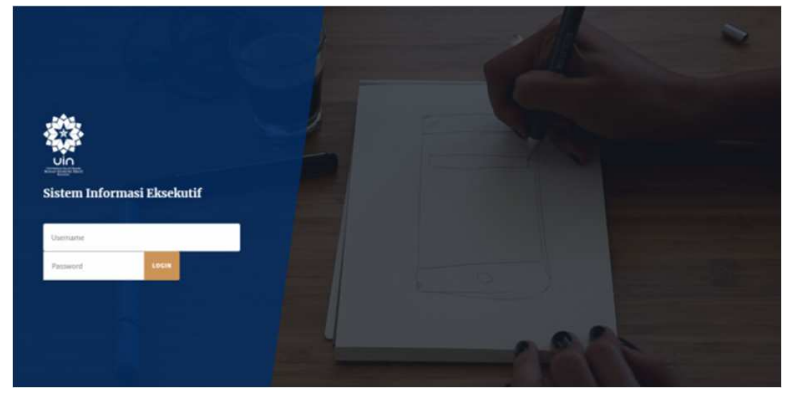

Fig. 9 Display of the login page

The main page is the view that appears after the admin logs in. The main page display as in Figure 10.

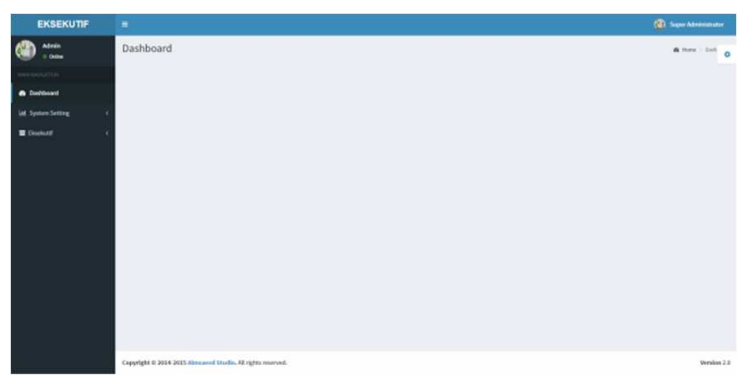

Fig. 10 Display of the Main Page

The filter page is a display that appears after the user clicks on the lecturer sub menu that often gives an A value, on this page the user must choose the category provided, namely the category of majors and semeter. The main page display as in Figure 11.

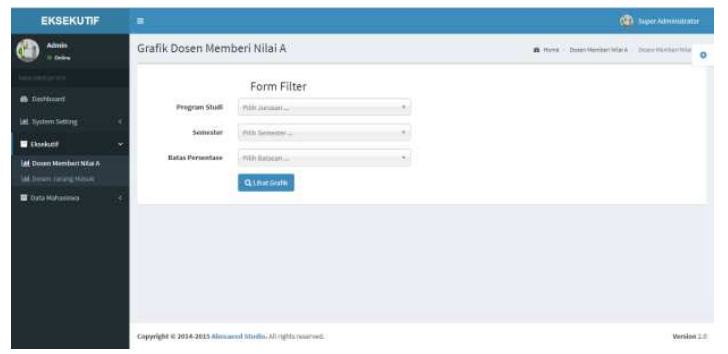

Fig. 11 Filter Page View 
This page is a display of lecturer data information that often gives an A value, the average value of lecturers, the average score of the survey results is displayed in the form of bar graphs. Lecturer graphic page display that often gives an A value as shown in figure 12

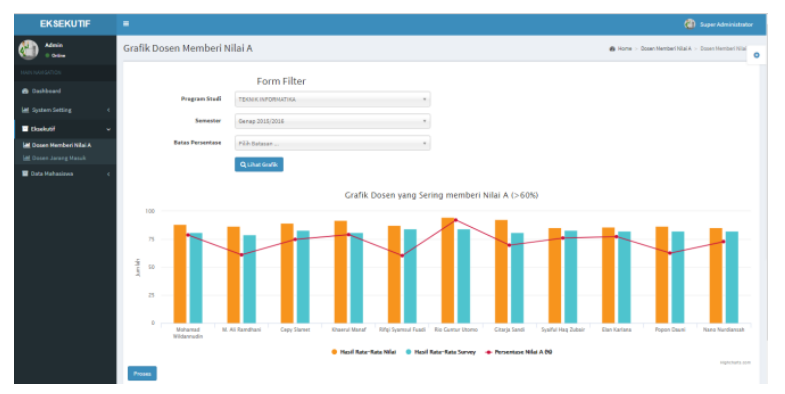

Fig. 12 Display of Lecturer Graphic Pages that Often Give A Value

This page is the view that appears when users click the process button on the previous page. This page aims to display the results of calculations using the mamdani inference system. To display the results of the calculation, the user must choose the name of the lecturer to be processed first, then the graph will appear. Display the calculation results as in Figure 13.

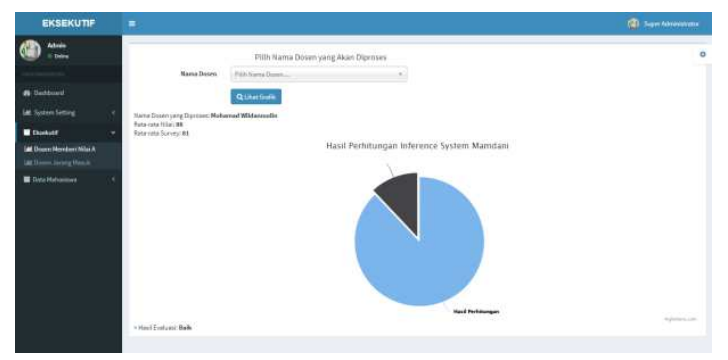

Fig. 13 Display of Calculation Results

This process is done by comparing the calculation of the application with manual calculation, the results obtained from the comparison are appropriate (valid) or not suitable (invalid) with manual calculations. 


\section{a. Testing Login page}

Table 2 Testing Login Page

\begin{tabular}{cllll}
\hline No. & Scenario & Expected results & Results on the application & Testing \\
\hline $\mathbf{1}$ & $\begin{array}{l}\text { Access the } \\
\text { system in the } \\
\text { browser }\end{array}$ & Can log in & Enter the main page & Corresponding \\
\hline $\mathbf{2}$ & $\begin{array}{l}\text { Input } \begin{array}{l}\text { username } \\
\text { and } \\
\text { password }\end{array} \\
\text { main page }\end{array}$ & $\begin{array}{l}\text { Click the login } \\
\text { button, enter the } \\
\text { main pand }\end{array}$ & Enter the login page & Corresponding \\
\hline
\end{tabular}

b. Testing the Main Page

Table 3 Testing the Main Page

\begin{tabular}{lllll}
\hline No. & \multicolumn{1}{c}{ Scenario } & $\begin{array}{c}\text { Expected } \\
\text { results }\end{array}$ & $\begin{array}{c}\text { Results on the } \\
\text { application }\end{array}$ & Testing \\
\hline Select menu & $\begin{array}{l}\text { Menu can be } \\
\text { accessed }\end{array}$ & $\begin{array}{l}\text { All menus can } \\
\text { be accessed }\end{array}$ & Corresponding \\
2 & Select the logout menu & $\begin{array}{l}\text { Return to the } \\
\text { login page }\end{array}$ & $\begin{array}{l}\text { Login page } \\
\text { appears }\end{array}$ & Corresponding \\
\hline
\end{tabular}

c. Filter Page Testing

Table 4 Testing Page Filter

\begin{tabular}{|c|c|c|c|c|}
\hline No. & Scenario & $\begin{array}{l}\text { Expected } \\
\text { results }\end{array}$ & $\begin{array}{c}\text { Results on } \\
\text { the } \\
\text { application }\end{array}$ & Testing \\
\hline 1 & Choose a department name & $\begin{array}{l}\text { Majors } \\
\text { name list } \\
\text { appear }\end{array}$ & $\begin{array}{l}\text { All } \\
\text { department } \\
\text { names } \\
\text { appear }\end{array}$ & Corresponding \\
\hline 2 & Select semester category & $\begin{array}{l}\text { Semester } \\
\text { list } \\
\text { appears }\end{array}$ & $\begin{array}{l}\text { Semester } \\
\text { list appears }\end{array}$ & Corresponding \\
\hline 3 & Click "View Graphic" & $\begin{array}{l}\text { Filter } \\
\text { categories, } \\
\text { data }\end{array}$ & $\begin{array}{l}\text { Data shows } \\
\text { the number } \\
\text { of lecturers }\end{array}$ & Corresponding \\
\hline
\end{tabular}




$$
\begin{array}{ll}
\text { appear by } & \text { who often } \\
\text { category } & \text { give an A } \\
\text { in } & \text { in graphic } \\
\text { graphical } & \text { form } \\
\text { form } &
\end{array}
$$

\begin{tabular}{|c|c|c|c|c|}
\hline No. & Scenario & $\begin{array}{l}\text { Expected } \\
\text { results }\end{array}$ & $\begin{array}{l}\text { Results on } \\
\text { the } \\
\text { application }\end{array}$ & Testing \\
\hline 1 & $\begin{array}{l}\text { The name of the lecturer who often gives } \\
\text { an A is displayed }\end{array}$ & $\begin{array}{l}\text { Value data } \\
\text { appears }\end{array}$ & $\begin{array}{l}\text { The name } \\
\text { of the } \\
\text { lecturer and } \\
\text { the number } \\
\text { of grades } \\
\text { appear in } \\
\text { graphic }\end{array}$ & Corresponding \\
\hline 2 & Click "process" & $\begin{array}{l}\text { Calculating } \\
\text { data based } \\
\text { on the } \\
\text { calculation } \\
\text { of the } \\
\text { mamdani } \\
\text { inference } \\
\text { system }\end{array}$ & $\begin{array}{l}\text { Shown the } \\
\text { graphic } \\
\text { calculation } \\
\text { results } \\
\text { inference } \\
\text { system } \\
\text { mamdani }\end{array}$ & Corresponding \\
\hline
\end{tabular}

\section{d. Testing Lecturer Graphic Pages that Often Give A Value}

Table 5 Testing of Lecturer Graphic Pages that Often Give A Value

\section{Conclusions and suggestions}

\subsection{Conclusions}

After analyzing, designing, implementing, and testing using prototype development methods and based on the previous chapters, it can be concluded that:

1. By designing and implementing a web-based lecturer performance app evaluation using the Mamdani Inference System method, the calculation results become more accurate and reduce the number of subjectivity.

2. This application is an indicator or benchmark for the performance of lecturers which will later be used as evaluation material. 


\subsection{Suggestions}

Looking at the results of research and development carried out by researcher, there are several suggestions to be conveyed so that this research can be developed again by further researchers, namely:

1. In further system development, it is recommended to add the notification feature directly to the lecturer concerned if the final result is less than the minimum set value,

2. In further system development, it is also recommended to add report features.

\section{References}

[1] A. Susanto, Sistem Informasi Manajemen: Konsep dan Pengembangan Secara Terpadu, I. Bandung, 2017.

[2] A. Dwi Sambudi, "Bab 2 (Teori Konsep Visualisasi dan Model Grafis)," 2017. [Online]. Available: https://apriandwisambudi.wordpress.com/2017/01/22/bab-2-teori-konsep-visualisasidan-model-grafis/. [Accessed: 14-Apr-2018].

[3] S. R. Andani, "FUZZY MAMDANI DALAM MENENTUKAN TINGKAT KEBERHASILAN DOSEN MENGAJAR," vol. 2013, no. semnasIF, pp. 57-65, 2013.

[4] Andi, "Definisi Kualitas (Ringkasan)," 2012. [Online]. Available: https://goblognyaandi.wordpress.com/2012/09/30/definisi-kualitas-ringkasan/. [Accessed: 14Apr-2018].

[5] A. Triyuniarta, S. Winiarti, and A. Pujiyanta, "APLIKASI LOGIKA FUZZY UNTUK PENDUKUNG KEPUTUSAN,” vol. 2009, no. semnasIF, pp. 1-7, 2009. 